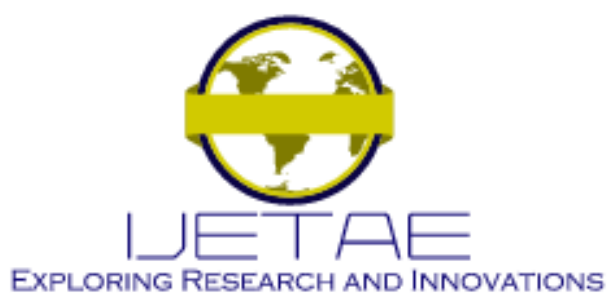

International Journal of Emerging Technology and Advanced Engineering

Website: www.ijetae.com (E-ISSN 2250-2459, Scopus Indexed, ISO 9001:2008 Certified Journal, Volume 11, Issue 10, October 2021)

Manuscript Received: 04 September 2021, Received in Revised form: 06 October 2021, Accepted: 12 October 2021

DOI: $10.46338 /$ ijetae1021_10

\title{
Tourism Digital Economy Model Based on Digital Transformation Concept for Tourist Village in Indonesia
}

\author{
Ratna Sari ${ }^{1}$, Harjanto Prabowo ${ }^{2}$, Ford Lumban Gaol $^{3}$, Fithra Faisal Hastiadi ${ }^{4}$, Meyliana ${ }^{5}$ \\ 1,5Information Systems Department, School of Information Systems, Bina Nusantara University, Jakarta 11480, Indonesia \\ ${ }^{1,2,3}$ Computer Science Department, BINUS Graduate Program-Doctor of Computer Science, Bina Nusantara University, Jakarta \\ 11480, Indonesia \\ ${ }^{2}$ Management Department, BINUS Business School Undergraduate Program, Bina Nusantara University, Jakarta 11480, \\ Indonesia \\ ${ }^{4}$ Faculty of Economics and Business Universitas Indonesia Depok, Indonesia
}

\begin{abstract}
The fast advancement of technology on a daily basis encourages the tourist industry to evolve and convert into a digital idea. The tourist hamlet as a tourism destination is the subject of this study, as is its culture and distinctiveness. The Indonesian country has 1734 tourist villages, but only a few are controlled and well maintained. While the tourist villages were expected to provide economic growth for the village community, the reality was that they provided only a few benefits and did not spread to all regions of the village. This study will concentrate on developing a tourist model using a digital economy strategy in order to demonstrate the idea of digital transformation. This model will assist the government in monitoring, controlling, and financing tourism activities, as well as in promoting and distributing products/services without the involvement of third parties, so that the government's enthusiasm for developing tourist villages from village communities to rural communities can be realized
\end{abstract}

Keywords-Tourism, Digital, Digital Tourism, Digital Economy, Model, Tranformation

\section{INTRODUCTION}

Tourism is a lucrative source of foreign currency for all countries. Leisure tourism is a ubiquitous component of our local, national, and global economies [1]. Indonesia is one of the countries with many tourist attractions that compete for development and marketing of existing tourist sites. It is unavoidable that technology advancements have an effect on the process of tourist marketing growth.

Indonesia is an archipelago nation blessed with natural beauty that has aided in the growth of tourism, which is well-known not only inside the country but has also extended to neighboring countries.
This scenario has resulted in the fast expansion of Indonesia's tourist sector; according to statistics provided by the ministry of tourism, the tourism industry in Indonesia expanded by 9.39 percent last year, while the economy grew by 5.04 percent. [2]

The tourism destination in Indonesia is not difficult to find; in addition to well-known destination cities, Indonesia now has a tourist village, also known as a tourist destination or tourism destination, which integrates tourist attractions, public facilities, tourism facilities, and accessibility, all of which are presented in a community structure. [3]

The minister of tourist mention about 1.734 tourist village from Sumatera, Jawa, Bali, Kalimantan, Nusa Tenggara, Sulawesi, Maluku until Papua. The biggest tourist village mention in Jawa, Bali island like shown in figure 1.

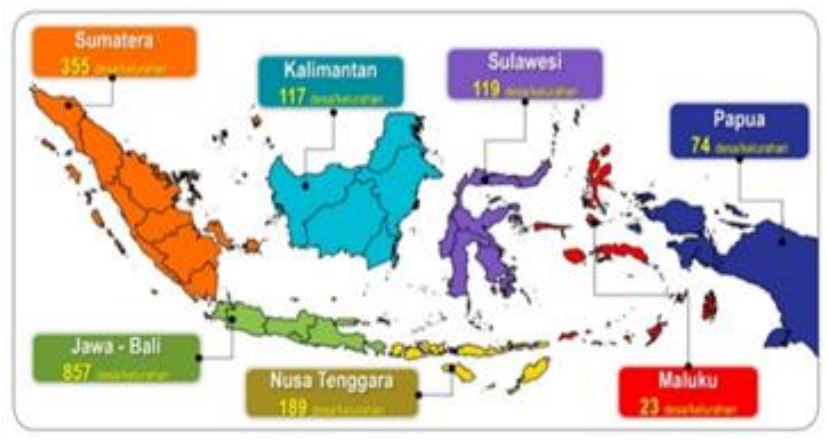

Figure 1 The Tourist Village in Indonesia Source: Gobumdes (2018) [4] 


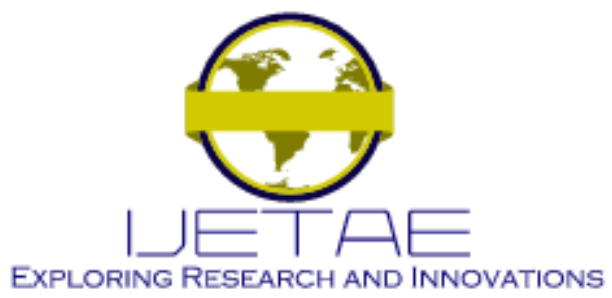

International Journal of Emerging Technology and Advanced Engineering

Website: www.ijetae.com (E-ISSN 2250-2459, Scopus Indexed, ISO 9001:2008 Certified Journal, Volume 11, Issue 10, October 2021)

In the large number of tourist villages, management is still considered non optimal, while the governance for tourist village still left behind comparing with another tourism destination. The progress of the tourism sector, especially tourist villages in Indonesia, is considered not to have a good impact on the lives of the surrounding community. The benefits of tourism progress have not been evenly distributed, the enthusiasm to build tourist villages from village communities to rural communities is also not evenly distributed.

The population around the tourism area is unknown except that they get a few benefits from tourism inside their own region, since Bali is a tourism paradise for both domestic and international visitors. Bali is blessed with incredible natural beauty and a plethora of culture, which makes it an exceptional tourist destination. If we look at Figure 1, Jawa and Bali are made up of 857 tourist villages. Given the present condition of Bali, growth seems to be accelerating, transforming it into a large metropolis that pampers visitors. This growth can be observed beginning with the arrival of visitors, who are greeted by the beautiful Airport, as well as the growing presence of internationalstandard hotels and restaurants in Bali. Of course, this scenario presupposes that Bali is presently a province with a high degree of welfare for its citizens. Unfortunately, the tourist and economic development that we witness in that place are not universal.

The tourism village is intended to enhance the local community's economic situation. Thus, the tourist village must be created in conjunction with other tourist attractions, adhere to the same standards and trends as other tourism destinations, while also growing and embracing technology, as is the case with the well-known digital tourism idea.

The term "digital tourism" refers to the process of transforming the tourist idea by beginning with the use of technology for all processes and information. It also refers to the application of contemporary information technology in travel and tourism processes. [5] Digital tourism has grown in popularity, particularly among tourist locations. According to prior study, digital tourism is associated with the digital economy. A digital economy is one that is centered on electronic products and services generated via e-commerce.
And do business through e-commerce, interacting with partners and consumers, and conducting business using Internet and Web technologies. This The term "digital economy" first emerged in the last decade of the twentieth century. [6] Additionally, the digital economy and tourism concepts are recognized as sectors capable of attracting and implementing in the tourism industry, as the tourism industry is confronted with growing customer-oriented demand, fierce international competition, market turmoil in an unsafe environment, and customer demand is increasingly personalized. [6].

As a result of the preceding literature, this study will concentrate on creating a tourism digital economy model that emphasizes the approach of tourist villages with a unique idea in Indonesia. The concept may assist the government in controlling, monitoring, and guaranteeing that tourist villages are implemented equitably across Indonesia.

\section{LITERATURE REVIEW}

\section{Digital Economy}

Digital economy is simplified process while all settle with digitalization approach. Digital economy recognized as term point of economy with information technology inside. [7] The first definition around year 2000 was came from Hartman [8] "by using any Internet plan as a medium of exchange, a virtual stage for actually conducting business, creating and exchanging value, conducting transactions, and forming one-to-one relationships"

The digital economy is not a standard classification of economic data, so there may be some disagreements about its meaning. Digital economy is an economy based on electronic goods and services produced by e-commerce and traded through e-commerce. That is, an enterprise with electronic production and management processes, it interacts with its partners and customers, and conducts transactions through Internet and Web technologies. The concept of the digital economy appeared in the last decade of the 20th century.[6]

According to basic characteristics of digital economy, Tapscoot [9] mentioned there was 12(twelve) characteristics show in table 1 below: 


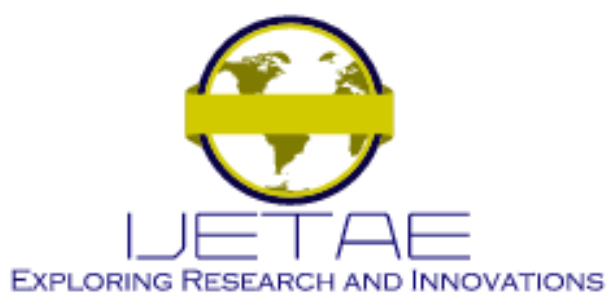

International Journal of Emerging Technology and Advanced Engineering

Website: www.ijetae.com (E-ISSN 2250-2459, Scopus Indexed, ISO 9001:2008 Certified Journal, Volume 11, Issue 10, October 2021)

Table 1

The Digital Economy Characteristics [9]

\begin{tabular}{|l|l|}
\hline \multicolumn{2}{|c|}{ Digital Economy Characteristics } \\
\hline 1. Knowledge & Understanding, the findings obtained in the development process [9] \\
\hline 2. Globalization & $\begin{array}{l}\text { Increases depend on each other in an activity, especially in the economy } \\
{[9],[10]}\end{array}$ \\
\hline 3. Virtualization & The simplified concept of something physical. [11] \\
\hline 4. Immediacy & $\begin{array}{l}\text { The relationship and distance between the source and the object being } \\
\text { communicated [9] }\end{array}$ \\
\hline 5. Innovation & The ability to create something different. [9],[10] \\
\hline 6. Digitalization & The process of transforming information in digital form [12] \\
\hline 7. Molecularization & Easy to adapt in dynamic conditions [9] \\
\hline 8. Internetworking & $\begin{array}{l}\text { Connect and integrate with each other to obtain, provide products / } \\
\text { services. [13] }\end{array}$ \\
\hline 9. Disintermediation & Direct process in distribution and direct transactions. [14] \\
\hline 10. Discordance & Anomalies, divisions, resulting from a unifying process. [9] \\
\hline 11. Convergence & Actions to meet, connect to a place/ place and collaborate. [15] \\
\hline 12. Prosumption & $\begin{array}{l}\text { Expansion and enhancement of the value chain that connects and integrates } \\
\text { consumers and producers. [16] }\end{array}$ \\
\hline
\end{tabular}

\section{Digital Tourism}

Digital tourism focuses on use digital technology to enhance the travel experience. This may be as mundane as posting a recommendation on a travel website, but it increasingly involves a mix of real world and digital content designed to enhance the visitor's experience. [17]

Previous research found, Digital tourism focuses on various destinations and environments, such as museums, assemblies, villages, zoos, theme parks and mobile devices are a popular mechanism in the context of tourism also geographic-centric navigation applications which these tools and methods are one of the few design techniques in the digital tourism field.[1]

Another research also found digital tourism is a new type of tourism value ecosystem based on high-tech services such as the Internet of Things (IoT) and the Internet of Services (IoS). Objects and services are connected to each other to realize the interaction between goods and other objects, and allow service providers to provide customers via the Internet Value suggestion.[18]

\section{Digital Tourism vs Traditional Tourism}

The growing and rapidly technology changes the process and give impact especially for tourism. The digitalized concept connecter with Information, Communication and Technology (ICT). The predictions of changes in tourism concept is starting to emerge while the internet and technology growth, the ICT culture help the tourism process likes: (1) connected and integration information; (2) integration process from order, transportation, and various sectors related with tourism; (3) establish linkage for marketing and endorsement support. [21].
According to Veiga [22] the reasons why tourism should change the process from traditional concept into digital concept was the tourist face due to millennials characteristics which disrupt the old habit and change into fast, digitalized, unique and memorable experience.

Another research shown, short survey took from the traveler whom enjoy the travelling if these technological criteria found:

Table 2

The Technological Criteria[22]

\begin{tabular}{|l|c|}
\hline \multicolumn{1}{|c|}{ Technology } & Percentage \\
\hline Internet Access & $88 \%$ \\
\hline Free Computer Services & $20 \%$ \\
\hline Online reservation process & $38 \%$ \\
\hline Pay \& Interactive TV & $10 \%$ \\
\hline Payment digital / transaction & $40 \%$ \\
\hline Multiconference & $10 \%$ \\
\hline
\end{tabular}

Tourism Digital Economy

The vital sector of Tourism from this day is synchronized with technology whom rapidly change. In the other hand tourism sector faced by growing customer expectation, competition with others. In developing countries, digital approach is not new for implementation, that's why technology adoption increase starting from information, promotion until services to the customer.

Digital economy and tourism adoption the improvement of process with technology and also the idea of economy which mention about sharing economy concept.

The idea of digital economy in tourism helps improved the tourism innovation with digitalization and also cut the third parties also internetworking from the administrator and customer.

Especially for tourist village in Indonesia, the digital economy concept will applicable for manage the process, change from the traditional into digital, create the innovation and also direct process and connect with the customer nor producers.

\section{Methodology}

The research methodology was qualitative in nature and comprised of literature reviews, an SLR approach, and focus group discussions (FGDs) with the ministries responsible for tourist villages: (1) the Ministry of Creative and Tourism; (2) the Ministry of Village; and (3) the Ministry of Communication and Information Technology (Division APTIKA KOMINFO). 


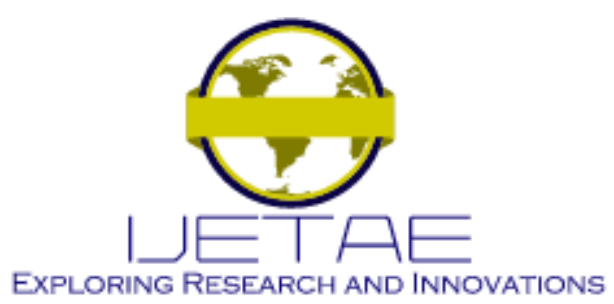

International Journal of Emerging Technology and Advanced Engineering

Website: www.ijetae.com (E-ISSN 2250-2459, Scopus Indexed, ISO 9001:2008 Certified Journal, Volume 11, Issue 10, October 2021)

This FGD seeks to develop a model that is consistent with the idea of digital economy and is applicable to tourism.

For the literature studies, the author began with a Systematic Literature Review (SLR) with the goal of identifying the general factors affecting the digital economy and sharing economy, as the concept of economy has shifted from traditional to digital, and digital economy also supports the sharing economy concept. [19]

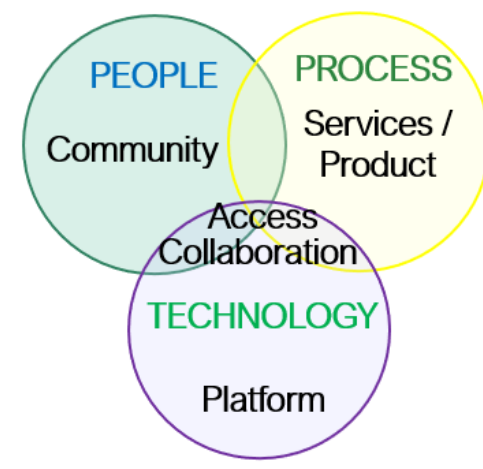

Figure 2 - General Factors of Digital Economy and Sharing Economy[19]

The general factors used PPT Framework (People, Process, Technology) approach by Bruce Schneiner[20] while after review and observed the literature author found 5(five) factors in between digital economy and sharing economy: (1) Community; (2) Services/Product; (3) Access; (4) Collaboration; (5) Platform. The detail of each factors mentioned detail in table 2 .

Table 2

Literature of General Factors Digital Economy and Sharing Economy[19]

\begin{tabular}{|l|l|}
\hline Community & $\begin{array}{l}\text { Reshaping urban development, consist } \\
\text { of people involved, providing, using or } \\
\text { just observing }\end{array}$ \\
\hline $\begin{array}{l}\text { Services \& } \\
\text { Product }\end{array}$ & $\begin{array}{l}\text { Offered nor shared in activity of digital } \\
\text { economy nor sharing economy }\end{array}$ \\
\hline Access & $\begin{array}{l}\text { The link and also the factor that } \\
\text { highlight in both concepts whom } \\
\text { provide convenience, to the community } \\
\text { for service/ product exchange }\end{array}$ \\
\hline Collaboration & $\begin{array}{l}\text { The integration of good people, process, } \\
\text { access, data to get service/ product. }\end{array}$ \\
\hline $\begin{array}{l}\text { Data, Platform \& } \\
\text { Technology }\end{array}$ & $\begin{array}{l}\text { The link between the community and } \\
\text { also explains the processes that occur in } \\
\text { the concept of digital economy or } \\
\text { sharing economy }\end{array}$ \\
\hline
\end{tabular}

\section{ANALYSIS AND DisCUSSION}

Prior study on the digital economy and tourism has concentrated on the process of transformation into the digital. The primary objective of tourism was to provide an appealing leisure environment for pleasure and, more importantly, to ensure that the destination would be remembered and that it would be able to return and become a favourite.

According to the tourist village, the concept and identity of this attraction are inspired by the town's culture and distinctiveness. The iconic of one village may differ from that of another; for example, the iconic of a tourist village in the near Java region was a temple; this is not to disparage Borobudur Temple, which is a large iconic and well-known temple that is also recognized as a world heritage site; however, in another region near Java, we can also find an older temple than Borobudur located in a tourist village but is not well maintained.

As a result, this model was developed to aid in the growth of tourist villages and to enable them to compete with other tourism destinations. After identifying the specifics of general factors, the author mapped the general elements from the digital economy that were identified as fundamental features, as well as mapping the factors as variables for this study.

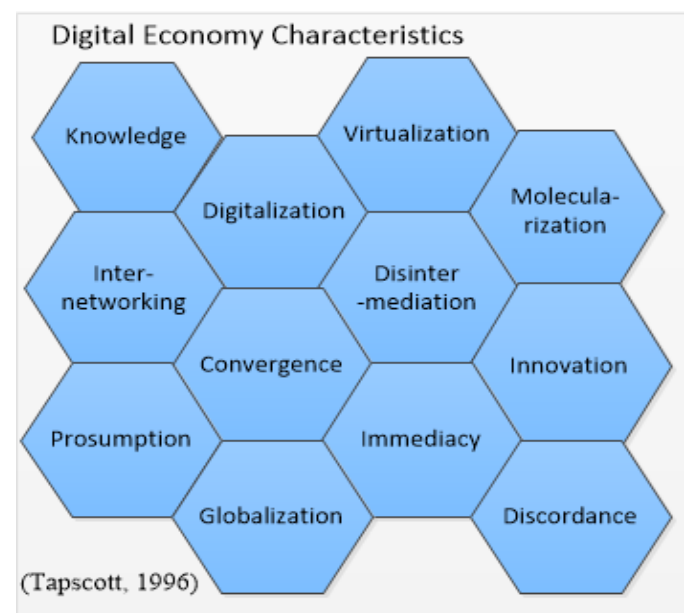

Figure 3. Digital Economy Characteristics [9]

Start from model development with PPT Framework, found the general factors and mapped with digital economy characteristics as shown in figure 4 . 


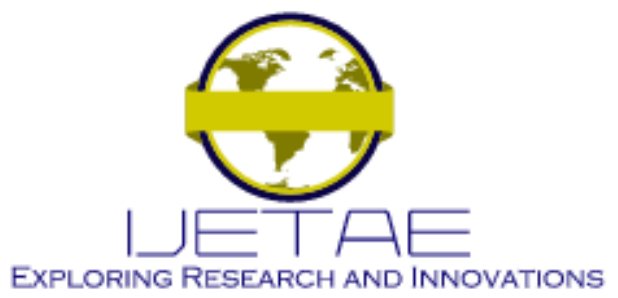

International Journal of Emerging Technology and Advanced Engineering

Website: www.ijetae.com (E-ISSN 2250-2459, Scopus Indexed, ISO 9001:2008 Certified Journal, Volume 11, Issue 10, October 2021)

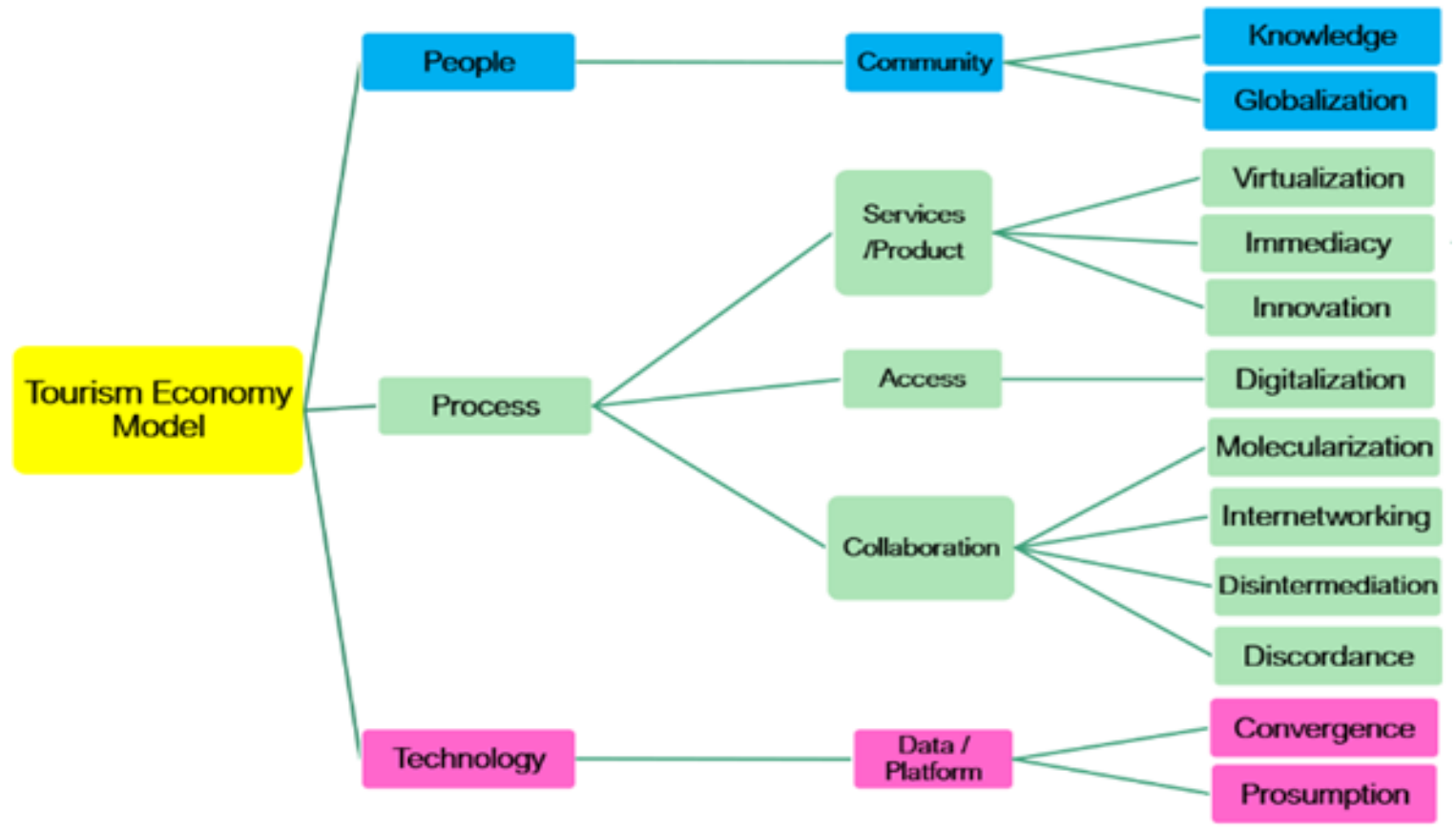

Figure 4. The Mapping General Factors and Digital Characteristics of Digital Economy

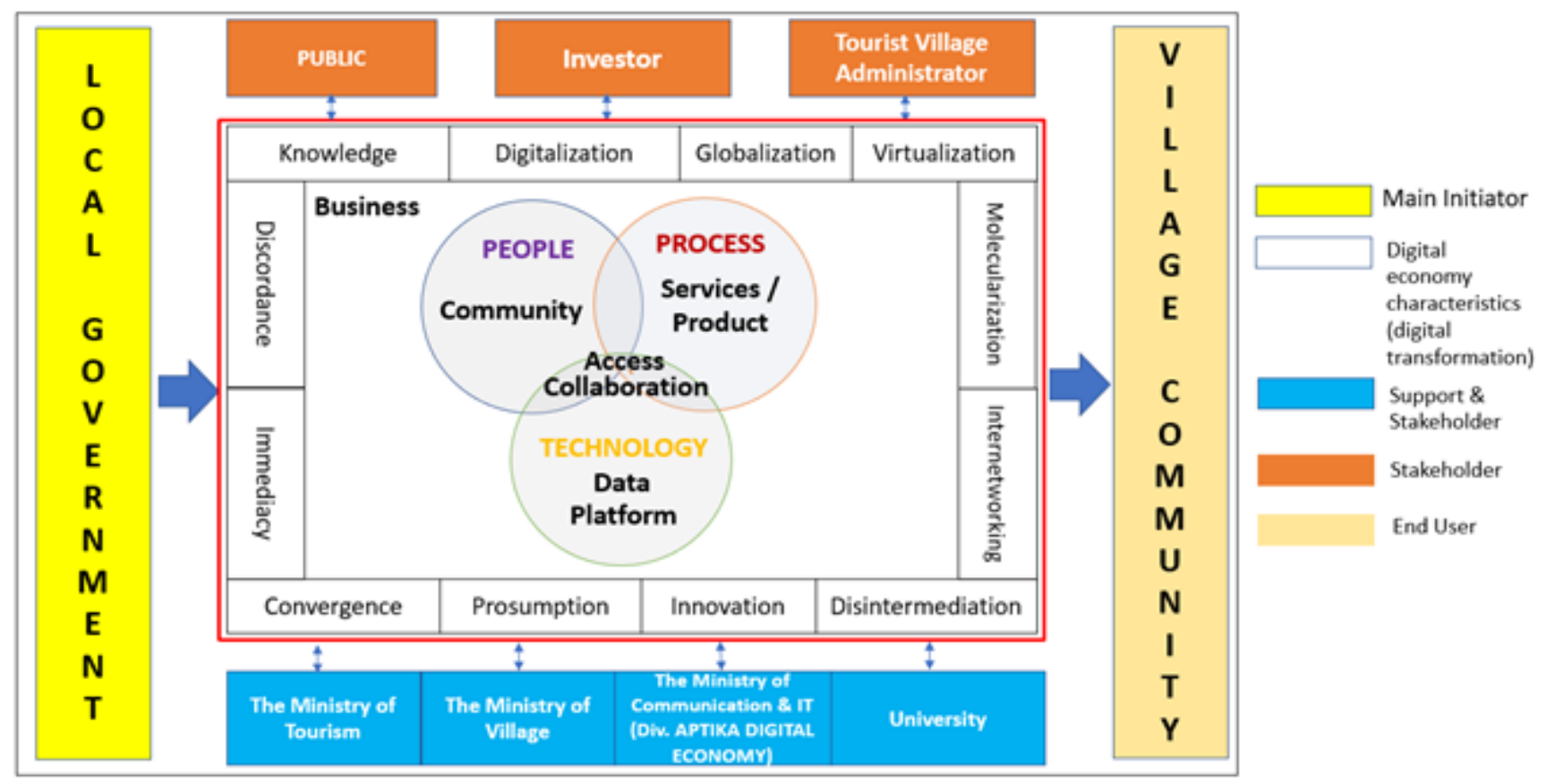

Figure 5 Tourism Digital Economy Model 


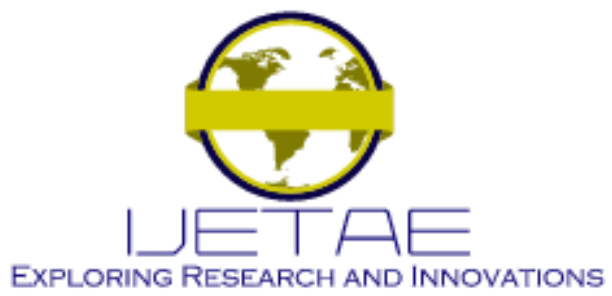

International Journal of Emerging Technology and Advanced Engineering

Website: www.ijetae.com (E-ISSN 2250-2459, Scopus Indexed, ISO 9001:2008 Certified Journal, Volume 11, Issue 10, October 2021)

The next step creates the detail model of tourism digital economy for figure out the flow and also show the part of stakeholder who responsible in tourist village. The model will help each stakeholder to monitor, control, maintain and also help the digitalization process especially in promote and spread the information according to tourist village.

According to the Tourism Digital Economy Model, here are the flow of the process:

1. This model show the flow and authorization starts from the local government who manage the governance in tourist village in their region.

2. The stakeholder especially highlight with blue colour will support, monitor, maintain the tourist village development.

- The Ministry of Tourism together with The Ministry of Village will help to monitor, coordination and support the process until financing for governance in tourist village.

- The Ministry of Communication and IT, in detail support with APTIKA Digital Economy help to create and develop the concept of digitalization according to implementation the digital economy concept.

- The university will support, accompany, the process and implementation assistance especially for knowledge supplies and training according to the digitalization and approach.

3. The stakeholder especially highlight with brown colour will have access and participation.

- The Public will get the information and also give the review and feedback according to the experience when they were in visit of tourist village.

- The investor will know the prospect of tourist village, while in the other hand together with the government support and develop the tourist village.

- The tourist village administrator will access, learn and also contribute to promote their village by put the information (also as information provider) and trend monitoring based on review and feedback from the public.

4. As the spirit of tourist village development, rapidly change the concept of tourism in tourist village will give impact to the village community as well.

5. The mapping factors between general factors of digital economy and sharing economy with 12(twelve) digital characteristics will convert into feature and functions in real development of digital approach.

\section{CONCLUSION}

This research aims to develop the model for tourism especially with digital economy approach. In order to support the tourist village in Indonesia, this research will help the government in control, monitor, until financing process as we know the tourist village in Indonesia recorded total 1.734 region. The process inspired by digital tourism and digitalization approach in rapidly technology change day by day.

The model will continue to the next process of research, process and analysis with qualitative in deep focus group discussion in order to support and find the right features to develop into prototyping with digitalization approach. The process will change from traditional into digital process starting from knowledge process, digitalized the information, change into global and create the innovation to support the tourist village improvement.

\section{REFERENCES}

[1] Benyon, David \& Quigley, Aaron \& Okeefe, Brian \& Riva, Giuseppe. (2014). Presence and digital tourism. AI \& Society. 29. 521-529. 10.1007/s00146-013-0493-8.

[2] Putra, Fajar Kusnadi Kusumah and Saepudin, Pudin and Adriansyah, Edwin and Wahyu Adrian, I Gusti Agung, Digital Tourism: A Content Analysis of West Java Tourism Websites (March 17, 2018). Putra, F. K. K., Saepudin, P., Adriansyah, E., \& Adrian, I. G. A. W. (2018). Digital Tourism: A Content Analysis of West Java Tourism Websites. Journal of Indonesian Tourism and Development Studies, 6(2), 73-84. doi: 10.21776/ub.jitode.2018.006.02.02, Available at SSRN: https://ssrn.com/abstract=3858464

[3] Gobumdes (2018). "Jumlah Desa Wisata Menurut Pulau di Indonesia 2018" retrieved from https://gobumdes.id/2019/03/23/jumlah-desa-wisata/

[4] "Tantangan 244 Desa Wisata se-Indonesia Menuju Desa Wisata Mandiri”. (2021) retrieved from https://lintasbali.com/tantangan244-desa-wisata-se-indonesia-menuju-desa-wisata-mandiri/2021/

[5] Happ, É., \& Ivancsó-Horváth, Z. (2018). Digital Tourism is The Challenge of Future-A New Approach to Tourism. Knowledge Horizons. Economics; Bucharest Vol. 10, Iss. 2, (2018): 9-16.

[6] Hojeghan, S. B., \& Esfangareh, A. N. (2011). Digital economy and tourism impacts, influences and challenges. Procedia-Social and Behavioral Sciences, 19, 308-316.

[7] Beat F. Schmid (2001) What is New About the Digital Economy?, Electronic Markets, 11:1, 44-51

[8] Hartman, A. (2000). The Search for Digital Excellence. US: McGraw-Hill Inc.

[9] Tapscott, D. (1996). The Digital Economy: Promise and Peril in the Age of Networked Intelligence. New York: McGraw-Hill.

[10] Ključnikov, Aleksandr \& Civelek, Mehmet \& Krajcik, Vladimir \& Kmeco, Lubomir. (2020). Innovations in Tourism Marketing: Sharing Economy Platform. Marketing and Management of Innovations. 11-25. 10.21272/mmi.2020.1-01. 


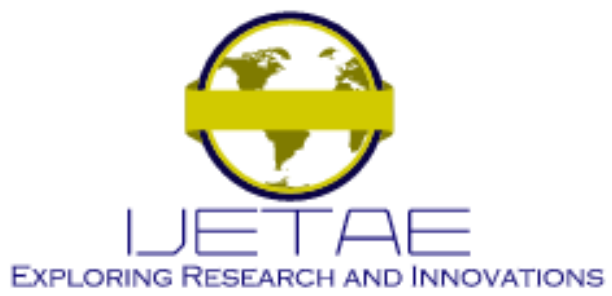

International Journal of Emerging Technology and Advanced Engineering

Website: www.ijetae.com (E-ISSN 2250-2459, Scopus Indexed, ISO 9001:2008 Certified Journal, Volume 11, Issue 10, October 2021)

[11] Sutherland, Will \& Jarrahi, Mohammad Hossein. (2018). The Sharing Economy and Digital Platforms: A Review and Research Agenda. International Journal of Information Management. 43. 10.1016/j.ijinfomgt.2018.07.004.

[12] Sammut-Bonnici, Tanya. (2015). The Internet of Things and the Sharing Economy. 10.13140/RG.2.1.1051.5285.

[13] Dredge, Dianne \& Gyimóthy, Szilvia. (2015). The collaborative economy and tourism: Critical perspectives, questionable claims and silenced voices. Tourism Recreation Research. 40. 1-17. 10.1080/02508281.2015.1086076.

[14] Kim, Yeji; Lee, Minhwa. 2019. "Typology and Unified Model of the Sharing Economy in Open Innovation Dynamics" J. Open Innov. Technol. Mark. Complex. 5, no. 4: 102. https://doi.org/10.3390/joitmc5040102

[15] Tian, J.M., Shen, L. and Chen, Y. (2017) A Study on Customer Prosumption Concept and Its Impact on Enterprise Value CoCreation. Theoretical Economics Letters, 7, 2040-2053.

[16] Dupeyras, A. and N. MacCallum (2013), "Indicators for Measuring Competitiveness in Tourism: A Guidance Document", OECD Tourism Papers, 2013/02, OECD Publishing. http://dx.doi.org/10.1787/5k47t9q2t923-en
[17] Voronkova, L.P. (2018) IOP Conf. Series: Materials Science and Engineering 463. 042096. IOP Publishing doi:10.1088/1757899X/463/4/042096

[18] Pencarelli, Tonino (2019). The digital revolution in the travel and tourism industry. Information Technology \& Tourism, (), . doi:10.1007/s40558-019-00160-3

[19] Sari, R. Gaol, F. L. Prabowo H and Hastiadi F. F., (2020). "The General Factors Mapping between Digital Economy and Sharing Economy," International Conference on Information Management and Technology (ICIMTech), 2020, pp. 621-625, doi: 10.1109/ICIMTech50083.2020.9211166.

[20] Schneier, B. (1999). Schneier on Security, Canada: Wiley Publishing Incorporation, 1999. ISBN13: 978-0470395356

[21] Shanker, D. (2008). ICT and Tourism: Challenges and Opportunities.

[22] Veiga, C., Santos, M. C., Águas, P., \& Santos, J. A. C. (2017). Are millennials transforming global tourism? Challenges for destinations and companies. Worldwide Hospitality and Tourism Themes, 9(6), 603-616. doi:10.1108/whatt-09-2017-0047 